\title{
PENGARUH IMPLEMENTASI PEMBELAJARAN INKUIRI BERBANTUAN LEMBAR KERJA SISWA TERHADAP KEMAMPUAN BEKERJASAMA DAN HASIL BELAJAR MATEMATIKA SISWA
}

\author{
D. Ayu Karmila Dewi' ${ }^{1}$ Sariyasa ${ }^{2}$, M. Gunamantha ${ }^{3}$ \\ ${ }^{123}$ Program Studi Pendidikan Dasar \\ Universitas Pendidikan Ganesha \\ Singaraja, Indonesia \\ e-mail: ayu.karmila@pasca.undiksha.ac.id ${ }^{1}$, sariyasa@undiksha.ac.id ${ }^{2}$ \\ made.gunamantha@undiksha.ac.id ${ }^{3}$
}

\begin{abstract}
Abstrak
Penelitian ini bertujuan untuk mengetahui pengaruh implementasi pembelajaran inkuiri berbantuan lembar kerja siswa dalam pembelajaran matematika terhadap kemampuan bekerjasama dan hasil belajar matematika siswa kelas IV SD di gugus VIII Mengwi tahun pelajaran 2019/2020. Penelitian ini adalah penelitian kuasi eksperimen dengan rancangan single factor independent groups. Populasi dalam penelitian ini adalah seluruh siswa kelas IV sekolah dasar di Gugus VIII Mengwi pada Tahun Pelajaran 2019/2020 yang terdiri dari 252 orang. Sampel dalam penelitian ini diambil menggunakan teknik random sampling. Berdasarkan teknik random sampling yang telah dilakukan didapatkan bahwa siswa kelas IV B SD No. 3 Mengwi yang berjumlah 25 orang sebagai kelompok eksperimen dan siswa kelas IV C SD No. 3 Mengwi yang berjumlah 27 orang sebagai kelompok kontrol. Data kemampuan bekerjasama siswa dikumpulkan dengan angket/kuesioner, sedangkan data hasil belajar matematika siswa dikumpulkan dengan tes pilihan ganda. Analisis data yang digunakan pada penelitian ini adalah Manova. Berdasarkan analisis data yang telah dilakukan, didapatkan hasil bahwa: 1) terdapat pengaruh yang signifikan implementasi pembelajaran inkuiri berbantuan lembar kerja siswa dalam pembelajaran matematika terhadap kemampuan bekerjasama siswa kelas IV SD di Gugus VIII Mengwi tahun pelajaran 2019/2020, 2) terdapat pengaruh yang signifikan implementasi pembelajaran inkuiri berbantuan lembar kerja siswa dalam pembelajaran matematika terhadap hasil belajar matematika siswa kelas IV SD di Gugus VIII Mengwi tahun pelajaran 2019/2020, dan 3) secara bersama-sama, terdapat pengaruh yang signifikan implementasi pembelajaran inkuiri berbantuan lembar kerja siswa dalam pembelajaran matematika terhadap kemampuan bekerjasama dan hasil belajar matematika siswa kelas IV SD di Gugus VIII Mengwi tahun pelajaran 2019/2020.
\end{abstract}

Kata Kunci : Hasil Belajar Matematika; Kemampuan Bekerjasama; Lembar Kerja Siswa; Pembelajaran Inkuiri

\begin{abstract}
This study aims to determine the effect of the implementation of inquiry learning aided by student worksheets in mathematics learning on the ability to cooperate and mathematics learning outcomes of fourth grade elementary school students in the VIII Mengwi group in 2019/2020. This study is a quasi-experimental study with a single factor independent groups design. The population in this study were all grade IV elementary school students in the VIII Mengwi Cluster in 2019/2020 Academic Year consisting of 252 people. The sample in this study was taken using a random sampling technique. Based on the random sampling technique, it was found that class IV $B$ with twenty five students SD No. 3 Mengwi as the experimental group and IV C with twenty seven students SD No. 3 Mengwi as the control group. Data on the ability to cooperate with students was collected by questionnaire / questionnaire, while the data on student mathematics learning outcomes were collected by multiple choice tests. Analysis of the data used in this study was Manova. Based on the analysis of the data that has been done, the results show that: 1) there is a significant influence on the implementation of inquiry learning aided by student worksheets in mathematics learning towards the ability to collaborate grade IV elementary school students in the VIII Mengwi Cluster in the academic year 2019/2020, 2) there is a significant influence implementation of inquiry learning assisted by student worksheets in mathematics learning towards mathematics learning outcomes of fourth grade
\end{abstract}


students in the VIII Mengwi Cluster 2019/2020 academic year, and 3) together, there is a significant influence on the implementation of inquiry learning assisted student worksheets in mathematics learning on the ability to cooperate and the results of mathematics learning fourth grade elementary school students in the VIII Mengwi Cluster 2019/2020 school year.

Keywords : Mathematics Learning Outcomes, Cooperative Ability, Student Worksheets, Inquiry Learning

\section{PENDAHULUAN}

Matematika merupakan salah satu disiplin ilmu yang dapat meningkatkan kemampuan berfikir dan berargumentasi, memberikan kontribusi dalam penyelesaian masalah sehari-hari di dalam dunia kerja, serta memberikan dukungan dalam pengembangan ilmu pengetahuan dan teknologi (Budiasih, 2017).

Menurut Nugroho (2017:1531) matematika merupakan mata pelajaran yang berfungsi untuk mengembangkan kemampuan hitung peserta didik, mengukur suatu benda menggunakan alat ukur sederhana, serta menggunakan rumus-rumus yang ada untuk diterapkan di kehidupan sehari-hari. Hal ini bermanfaat untuk mengembangkan aktivitas kreatif yang melibatkan imajinasi dengan mengembangkan rasa ingin tahu, dugaan dan membuat prediksi serta memecahkan suatu bentuk masalah yang ada.

Pendapat senada juga disampaikan oleh Strike (2018:363) bahwa matematika adalah sebuah pengetahuan dasar yang harus dikuasai oleh setiap peserta didik, yang nantinya dapat digunakan peserta didik untuk kehidupannya di masa mendatang.

Namun sayangnya, siswa Indonesia memperolah hasil yang kurang baik dalam hasil tes matematika yang diadakan oleh Programme for International Student Assessment (PISA) dan Trends in International Mathematics and Science Study (TIMSS). Hasil TIMSS 2015 menunjukkan prestasi siswa Indonesia dalam literasi matematika mendapat peringkat 46 dari 51 negara, dengan pencapaian skor 397dan masih di bawah skor rata-rata Internasional (Afriansyah, 2017:463).

Sedangkan pada PISA yang diselenggarakan pada tahun 2018, siswa Indonesia memperoleh nilai rata-rata 379 di bidang matematika, sementara nilai rata-rata di bidang matematika dari OECD adalah 489 (Kemendikbud, 2019).

Penelitian lainnya yang khusus mengkaji hasil belajar matematika juga menunjukkan hasil yang kurang memuaskan. Rawa (2019) menemukan bahwa hasil belajar matematika siswa yang kurang optimal, walaupun guru telah memberikan penjelasan namun masih ada beberapa siswa yang kurang paham. Budiasih (2017) menemukan hasil belajar matematika siswa masih rendah disebabkan penerapan metode pembelajaran matematika yang masih berpusat pada guru (teacher oriented), sementara siswa cenderung pasif. Observasi yang dilakukan Wiryawati (2020) memperoleh hasil bahwa banyak siswa yang menganggap matematika sebagai salah satu mata pelajaran yang menakutkan membuat siswa menjadi kurang tertarik untuk mempelajari matematika.

Mengingat pentingnya pendidikan matematika dan permasalahan yang dipaparkan di atas, maka kualitas pendidikan matematika harus ditingkatkan. Guru hendaknya menerapkan model pembelajaran yang membuat siswa lebih aktif dalam kegiatan pembelajaran. Guru juga harus membantu siswa untuk membangun pengetahuannya sendiri sehingga pengetahuan tersebut lebih melekat dalam ingatan siswa. Keberhasilan pendidikan dan pengajaran bukan hanya ditentukan oleh guru tetapi juga oleh siswanya. Siswa memainkan peran penting, untuk mempersiapkan dirinya menjadi aktor yang mampu menampilkan keunggulan dirinya sebagai sosok yang tangguh, kreatif, mandiri, dan profesional pada bidangnya masingmasing (Widiani, 2020).

Salah satu model pembelajaran yang membantu siswa menjadi aktor yang 
mampu menampilkan keunggulan dirinya adalah model pembelajaran inkuiri.Model pembelajaran inkuiri adalah model pembelajaran penemuan. Siswa akan dituntut untuk menemukan serta mencari jawaban atas suatu permasalahan yang tentunya dilakukan dengan cara sistematis, logis dan kritis dan dianalisis dengan perhitungan yang matang. Menurut Laksana (2017:3) pembelajaran inkuiri dapat membantu siswa menjadi lebih mandiri dan bertanggung jawab. Hal ini senada dengan pendapat Dasna (dalam Rawa, 2018) yang menyatakan bahwa Inkuiri adalah suatu strategi yang digunakan dalam pembelajaran yang dapat meningkatkan partisipasi peserta didik dalam pembelajaran melalui kegiatan pengamatan, penelitian, membuat penjelasan dari data yang diperoleh, menyimpulkan, dan mengkomunikasikan hasil temuan.

Dalam pembelajaran inkuiri, siswa akan lebih mudah menyelesaikan permasalahan apabila mereka bekerjasama di dalam kelompokkelompok belajar. Guru hendaknya memfasilitasi siswa belajar secara berkelompok sehingga muncul sikap kerjasama serta dapat menghilangkan rasa ego pada diri siswa. Kerjasama merupakan salah satu keterampilan abad - 21 yang diberi istilah 4C yaitu berpikir kritis (Critical Thinking), kerjasama/kolaborasi (Collaboration), kreatif (Creativity), komunikasi (Communication).

Menurut Ningrum (2018) kerjasama adalah kegiatan yang dilakukan oleh sekelompok orang untuk menyelesaikan tugas secara bersama sama. Kerjasama biasanya muncul karena adanya kepentingan atau keperluan yang sama. Kerjasama memberikan banyak manfaat bagi siswa diantaranya pekerjaan atau tugas dapat diselesaikan dengan cepat, beban masing-masing individu menjadi lebih ringan, melatih kemampuan mengeluarkan pendapat, serta memberikan kesempatan untuk saling bertukar pikiran. Hal ini senada dengan pendapat Rosita \& Leonard (dalam Khasanah, 2018) bahwa komunitas belajar lebih baik hasilnya dari pada individu yang belajar secara sendirisendiri sehingga tujuan dari pembelajaran cepat tercapai.

Guru dapat mendukung pelaksanaan pembelajaran inkuiri dan proses kerjasama siswa dalam kelompok dengan memberikan Lembar Kerja Siswa (LKS). Menurut Fathoni (2018) LKS merupakan bahan ajar yang dicetak dan berupa lembaran yang berisi materi, ringkasan, petunjuk, pelaksanaan tugas pembelajaran yang telah mengacu pada kompetensi dasar.

Senada dengan pendapat Trianto (dalam Wahidah, 2018) yang menyatakan lembar kerja siswa memuat sekumpulan kegiatan-kegiatan dasar yang harus dilakukan oleh siswa untuk memaksimalkan pemahaman dalam upaya pembentukan kemampuan dasar sesuai indikator pencapaian hasil belajar yang harus ditempuh.

Tujuan dari penelitian ini untuk mengetahui pengaruh yang signifikan implementasi pembelajaran inkuiri berbantuan lembar kerja siswa dalam pembelajaran matematika terhadap kemampuan bekerjasama dan hasil belajar siswa kelas IV gugus VII Mengwi tahun pelajaran 2019/2020.

\section{METODE}

Penelitian ini adalah penelitian eksperimen semu (quasi experiment) karena tidak semua variabel yang muncul dalam kondisi eksperimen dapat dikontrol dengan ketat. Populasi penelitian adalah seluruh siswa kelas IV sekolah dasar di Gugus VIII Mengwi pada Tahun Pelajaran 2019/2020 yang terdiri dari 252 orang.

Sampel yang digunakan dalam penelitian ini terdiri dari dua kelompok sampel yaitu kelompok eksperimen dan kelompok kontrol. Sampel tersebut diambil secara acak dari populasi menggunakan teknik random sampling. Berdasarkan random sampling dengan undian diperoleh bahwa seluruh siswa kelas IV B SD No. 3 Mengwi yang berjumlah sebanyak 25 orang sebagai kelompok eksperimen dan seluruh siswa kelas IV C SD No. 3 Mengwi yang berjumlah sebanyak 27 orang sebagai kelompok kontrol. 
Variabel-variabel eksperimen dalam penelitian ini berupa variabel bebas dan variabel terikat. Variabel bebas adalah pembelajaran pembelajaran inkuiri berbantuan lembar kerja siswa dan model pembelajaran konvensional serta variabel terikatnya adalah kemampuan bekerjasama dan hasil belajar matematika.

Data yang dikumpulkan dalam penelitian ini adalah data tentang kemampuan bekerjasama dan hasil belajar siswa. Metode pengumpulan data dalam penelitian ini adalah menggunakan angket untuk mengukur kemampuan bekerjasama dan metode tes untuk mengukur hasil belajar matematika.

Data yang diperoleh dari penelitian dideskripsikan menurut masing-masing variabel, karena tujuannya demikian, maka dicari harga rerata $(\mathrm{M})$, standar deviasi (SD), modus (Mo), dan median $(\mathrm{Me})$ setiap variabel yang diteliti.

Uji prasyarat analisis dilakukan untuk memeriksa data dan varians antar kelompok. Adapun persyaratan yang berkaitan dengan pengujian prasayarat analisis dalam penelitian adalahi: (1) uji normalitas sebaran data, (2) uji homogenitas variansi, dan (3) uji korelasi antar variabel terikat.

Pengujian hipotesis pertama dan kedua menggunakan analisis varian satu jalur (ANAVA A). Kriteria yang digunakan adalah dengan membandingkan harga $F_{\text {hit }}$ dengan $F_{\text {tabel }}$ pada taraf signifikan 5\% dengan $\mathrm{db}$ pembilang (a-1) dan $\mathrm{db}$ penyebut $(\mathrm{N}-\mathrm{a})$. Aturan keputusan dalam perhitungan ini adalah jika $F_{\text {hit }}$ lebih besar dari pada $\mathrm{F}_{\text {tabel, }}$ maka $\mathrm{H}_{\mathrm{a}}$ diterima dan $\mathrm{H}_{0}$ ditolak yang artinya terdapat perbedaan variabel dependen antar kelompok.

Selanjutnya dilakukan uji MANOVA untuk menguji hipotesis ketiga, dengan analisis Pillace Trace Wilks Lamda, Hotelling's Trace, dan Roy's Largest Root. Kriteria pengujiannya, yaitu:(1) jika nilai $F$ untuk Pillai's Trace, Wilks' Lambda, Hotelling's Trace, dan Roy's Largest Root memiliki signifikansi yang lebih dari 0,05, maka hipotesis nol diterima dan hasilnya tidak signifikan; dan (2) jika nilai $F$ untuk Pillai's Trace, Wilks' Lambda, Hotelling's Trace, dan Roy's Largest Root memiliki signifikansi yang kurang dari 0,05, maka hipotesis nol ditolak dan hasilnya signifikan.

\section{HASIL DAN PEMBAHASAN}

Ringkasan hasil analisis statistik data kemampuan bekerjasama dan hasil belajar matematika pada masing-masing kelompok sampel disajikan pada tabel berikut ini.

Tabel 1. Rekapitulasi Deskripsi Data Hasil Penelitian

\begin{tabular}{|c|c|c|c|c|}
\hline Statistik Data & A1Y1 & $\mathrm{A} 2 \mathrm{Y} 1$ & A1Y2 & $\mathrm{A} 2 \mathrm{Y} 2$ \\
\hline $\mathrm{N}$ & 25 & 25 & 27 & 27 \\
\hline $\operatorname{Mean}(\overline{\bar{X}})$ & 84,56 & 15,56 & 75 & 13,4815 \\
\hline Median & 84 & 16 & 75 & 14 \\
\hline Modus & 83 & 14 & 78 & 14 \\
\hline Standar Deviasi (SD) & 4,13 & 2,06 & 5,00 & 2,28 \\
\hline Varians $\left(S^{2}\right)$ & 17,09 & 4,26 & 25,00 & 5,18 \\
\hline Range & 17 & 8 & 20 & 9 \\
\hline Skor Minimum $\left(X_{\min }\right)$ & 76 & 11 & 65 & 8 \\
\hline Skor Maksimum ( $\left.X_{\text {makss }}\right)$ & 93 & 19 & 85 & 17 \\
\hline Jumlah & 2114 & 389 & 2025 & 364 \\
\hline
\end{tabular}

Keterangan

A1Y1 : Deskripsi data kemampuan bekerjasama siswa yang mengikuti pembelajaran inkuiri berbantuan lembar kerja siswa 
A2Y1 : Deskripsi data kemampuan bekerjasama siswa yang mengikuti pembelajaran konvensional

A1Y2 : Deskripsi data hasil belajar Matematika siswa yang mengikuti pembelajaran inkuiri berbantuan lembar kerja siswa

A2Y2 : Deskripsi data hasil belajar Matematika siswa yang mengikuti pembelajaran konvensional

Tabel 2. Rangkuman Uji Hipotesis Pertama

\begin{tabular}{llccccc}
\hline $\begin{array}{c}\text { Variabel } \\
\text { Terikat }\end{array}$ & Sumber & JK & Df & RJK & F & Sig. \\
\hline $\begin{array}{l}\text { Kemampuan } \\
\text { bekerjasam }\end{array}$ & Antar & 1186,35 & 1 & 1186,359 & 55,952 & 0,000 \\
a & 9 & & & & \\
& Dalam & 1060,16 & 50 & 21,203 & & \\
& 0 & & & & \\
\hline
\end{tabular}

Berdasarkan analisis pada tabel 2, diperoleh nilai $F$ sebesar 55,952 dan memiliki nilai signifikansi lebih kecil dari 0,05 yaitu sebesar 0,000 . Ini menunjukan nilai $F$ signifikan pada kemampuan bekerjasama. Jadi, dapat disimpulkan terdapat pengaruh yang signifikan implementasi pembelajaran inkuiri berbantuan lembar kerja siswa dalam pembelajaran matematika terhadap kemampuan bekerjasama siswa.

Salah satu mata pelajaran yang penting untuk dikuasai siswa di era revolusi industri 4.0 ini adalah matematika. Menurut Nugroho (2017:1531) matematika merupakan mata pelajaran yang berfungsi untuk mengembangkan kemampuan hitung peserta didik, mengukur suatu benda menggunakan alat ukur sederhana, serta menggunakan rumus-rumus yang ada untuk diterapkan di kehidupan seharihari. Hal ini bermanfaat untuk mengembangkan aktivitas kreatif yang melibatkan imajinasi dengan mengembangkan rasa ingin tahu, dugaan dan membuat prediksi serta memecahkan suatu bentuk masalah yang ada.

Mengingat pentingnya pendidikan matematika dan permasalahan yang dipaparkan di atas, maka kualitas pendidikan matematika harus ditingkatkan. Guru hendaknya menerapkan model pembelajaran yang membuat siswa lebih aktif dalam kegiatan pembelajaran. Guru juga harus membantu siswa untuk membangun pengetahuannya sendiri sehingga pengetahuan tersebut lebih melekat dalam ingatan siswa.

Siswa dapat membangun pengetahuannya sendiri apabila guru penerapkan model pembelajaran yang berorientasi pada siswa. Salah satunya adalah model pembelajaran inkuiri. Model pembelajaran inkuiri adalah model pembelajaran penemuan. Siswa akan dituntut untuk menemukan serta mencari jawaban atas suatu permasalahan yang tentunya dilakukan dengan cara sistematis, logis dan kritis dan dianalisis dengan perhitungan yang matang. Model pembelajaran inkuiri jelas akan lebih menjadikan siswa untuk selalu terlibat dan banyak berdiskusi dalam penerapannya. Hal ini senada dengan pendapat Trianto (dalam Nurmayani, 2018:99) yang menyatakan inkuiri adalah model pembelajaran yang menuntun siswa untuk menyelidiki suatu permasalahan, menganalisis permasalahan secara kritis dan logis, mencari dan menemukan sendiri jawaban dari permasalahan tersebut sehingga seluruh kemampuan siswa ikut terlibat untuk menemukan jawaban dari permasalahan yang diselidiki.

Dalam pembelajaran inkuiri, siswa akan lebih mudah menyelesaikan permasalahan apabila mereka bekerjasama di dalam kelompokkelompok belajar. Guru hendaknya memfasilitasi siswa belajar secara berkelompok sehingga muncul sikap kerjasama serta dapat menghilangkan 
rasa ego pada diri siswa. Kerjasama merupakan salah satu keterampilan abad - 21 yang diberi istilah 4C yaitu berpikir kritis (Critical Thinking), kerjasama/kolaborasi (Collaboration ), kreatif (Creativity), komunikasi (Communication).

Menurut Ningrum (2018) kerjasama adalah kegiatan yang dilakukan oleh sekelompok orang untuk menyelesaikan tugas secara bersama-sama. Kerjasama biasanya muncul karena adanya kepentingan atau keperluan yang sama.

Menurut Suciani, dkk (2018) kemampuan kerjasama penting untuk dikembangkan dalam diri anak karena merupakan salah satu komponen dalam bidang sosial emosional. Kemampuan kerjasama merupakan kemampuan berkomunikasi, bertanggung jawab, saling tolong-menolong, menyelesaikan tugas bersama-sama untuk kepentingan bersama. Kemampuan kerjasama penting distimulasi sejak dini. Kerjasama mengajarkan anak bagaimana cara berbagi, saling membantu, berinteraksi dan komunikasi dengan teman sebaya, menyelesaikan masalah dalam kelompok dan bertanggung jawab yang bermanfaat bagi perkembangan sosial emosional anak.

Sejalan dengan penelitian yang dilakukan oleh Pratiwi, (2018) yang berjudul Peningkatan Kemampuan Kerjasama Melalui Model Project Based Learning (Pjbl) Berbantuan Metode Edutainment Pada Mata Pelajaran IImu Pengetahuan Sosial. Dimana penelitian ini bertujuan mendeskripsikan kemampuan bekerjasama siswa pada aspek menyelesaikan tugas proyek, mendiskusikan rencana proyek, saling tukar pendapat, dan kekompakan dalam menyelesaikan tugas proyek.

Berdasarkan pemaparan di atas, dapat disimpulkan bahwa terdapat pengaruh yang signifikan implementasi pembelajaran inkuiri berbantuan lembar kerja siswa dalam pembelajaran matematika terhadap kemampuan bekerjasama siswa. Pembelajaran inkuiri memotivasi siswa untuk bekerjasama dalam menyelesaikan permasalahan yang diberikan.

Tabel 3. Rangkuman Uji Hipotesis Kedua

\begin{tabular}{clccccc}
\hline $\begin{array}{c}\text { Variabel } \\
\text { Terikat }\end{array}$ & Sumber & JK & Df & RJK & F & Sig. \\
\hline Hasil belajar & Antar & 56,080 & 1 & 56,080 & 11,836 & 0,001 \\
Matematika & Dalam & 236,901 & 50 & 4,738 & & \\
\cline { 2 - 7 } & Total & 11197 & 52 & & & \\
\hline
\end{tabular}

Berdasarkan analisis terhadap tabel 3 di atas, diperoleh nilai $F$ sebesar 11,836 dengan nilai signifikansi 0,001 atau lebih kecil dari 0,05 . Terlihat bahwa nilai $F$ pada variabel terikat hasil belajar Matematika signifikan. Sehingga dapat ditarik kesimpulan bahwa terdapat pengaruh yang signifikan implementasi pembelajaran inkuiri berbantuan lembar kerja siswa dalam pembelajaran matematika terhadap hasil belajar matematika siswa.

Pembelajaran inkuiri menekankan kepada aktivitas siswa secara maksimal untuk mencari dan menemukan, artinya inkuiri menempatkan siswa sebagai subyek belajar. Dalam proses pembelajaran, siswa tidak hanya berperan sebagai penerima pelajaran melalui penjelasan dari guru secara verbal, tetapi mereka berperan untuk menemukan sendiri inti dari materi pelajaran itu sendiri. Pembelajaran inkuiri bertujuan mengembangkan kemampuan berpikir siswa secara sistematis, logis, dan kritis, atau mengembangkan kemampuan intelektual sebagai proses dari proses mental. Dengan demikian, siswa tak hanya dituntut agar menguasai materi pelajaran, akan tetapi bagaimana mereka dapat menggunakan potensi yang dimilikinya.

Menurut Ariyani (2018:4) model pembelajaran inkuiri merupakan model pembelajaran yang berupaya menanamkan dasar-dasar berpikir ilmiah pada diri anak, sehingga dalam proses pembelajaran ini anak lebih banyak 
belajar sendiri, mengembangkan kreativitas dalam memecahkan masalah. Anak benar-benar ditempatkan sebagai subjek yang belajar, peranan guru dalam pembelajaran dengan model inkuiri adalah sebagai pembimbing dan fasilitator.

Model pembelajaran inkuiri akan lebih efektif diterapkan apabila diperbantukan dengan lembar kerja siswa. Tujuan pembuatan Lembar Kerja Siswa adalah sebagai berikut: (1) Siswa memperoleh pengalaman konkret, (2) Belajar menjadi bervariasi, (3) Minat belajar siswa semakin meningkat, (4) Kemampuan mengingat materi pelajaran semakin meningkat, dan (5) Waktu belajar menjadi efektif dan efisien.

Hasil penelitian ini didukung oleh penelitian yang dilakukan Rawa (2019) tentang pengaruh model inquiry learning terhadap hasil belajar matematika pada siswa kelas IV SD. Hasil penelitian ini yaitu terdapat perbedaan yang signifikan hasil belajar matematika antara siswa yang mengikuti pembelajaran dengan menggunakan model Inquiry Learning dengan kelompok siswa yang menggunakan model pembelajaran langsung, sehingga dapat disimpulkan bahwa model Inquiry Learning berpengaruh terhadap hasil belajar matematika

Berdasarkan pemaparan di atas terlihat bahwa implementasi model pembelajaran inkuiri berbantuan lembar kerja siswa akan membuat siswa menjadi aktif, bersemangat dan bertanggung jawab dalam belajar. Hal ini tentunya berdampak positif terhadap hasil belajar Matematika siswa. Maka dari itu, dapat disimpulkan bahwa implementasi pembelajaran inkuiri berbantuan lembar kerja siswa dalam pembelajaran matematika berpengaruh signifikan terhadap hasil belajar matematika siswa.

Tabel 4. Ringkasan Uji Multivariat

\begin{tabular}{lccc}
\hline \multicolumn{1}{c}{ Statistik } & Nilai F & Taraf Signifikansi (sig.) & Kesimpulan \\
\hline Pillai's Trace & 38,750 & 0,000 & Signifikan \\
Wilks' Lambda & 38,750 & 0,000 & Signifikan \\
Hotelling's Trace & 38,750 & 0,000 & Signifikan \\
Roy's Largest Root & 38,750 & 0,000 & Signifikan \\
\hline
\end{tabular}

Pengujian hipotesis ketiga mendapatkan nilai $\mathrm{F}$ untuk Pillai's Trace, Wilks' Lambda, Hotelling's Trace, dan Roy's Largest Root sebesar 38,750 memiliki nilai signifikansi lebih kecil daripada 0,05. Maka dari itu, harga $F$ untuk Pillai's Trace, Wilks' Lambda, Hotelling's Trace, dan Roy's Largest Root signifikan. Jadi, dapat disimpulkan bahwa secara bersama-sama, terdapat pengaruh yang signifikan implementasi pembelajaran inkuiri berbantuan lembar kerja siswa dalam pembelajaran matematika terhadap kemampuan bekerjasama dan hasil belajar matematika siswa.

Menurut Nugroho (2017:1531) matematika merupakan mata pelajaran yang berfungsi untuk mengembangkan kemampuan hitung peserta didik, mengukur suatu benda menggunakan alat ukur sederhana, serta menggunakan rumus-rumus yang ada untuk diterapkan di kehidupan sehari-hari. Hal ini bermanfaat untuk mengembangkan aktivitas kreatif yang melibatkan imajinasi dengan mengembangkan rasa ingin tahu, dugaan dan membuat prediksi serta memecahkan suatu bentuk masalah yang ada.

Pembelajaran matematika di sekolah sangat tepat dibelajarkan dengan pembelajaran inkuiri. Menurut Anggareni (dalam Anggraini, 2020) yang menyatakan bahwa pembelajaran inkuiri dirancang dengan tujuan mengembangkan peserta didik agar memiliki kemampuan ilmiah, dan juga memotivasi melakukan keterlibatan langsung dalam proses pembelajaran. Inkuiri memberikan peserta didik pengalaman-pengalaman belajar nyata dan aktif.

Kelebihan pembelajaran inkuiri yaitu: (1) Pembelajaran ini merupakan pembelajaran yang menekankan kepada pengembangan aspek kognitif, afektif, dan 
psikomotor secara seimbang, sehingga pembelajaran melalui pembelajaran ini dianggap jauh lebih bermakna. (2) Pembelajaran ini dapat memberikan ruang kepada siswa untuk belajar sesuai dengan gaya mereka. (3) Pembelajaran ini merupakan strategi yang dianggap sesuai dengan perkembangan psikologi belajar moderen yang menganggap belajar adalah proses perubahan tingkah laku berkat adanya pengalaman. (4) Keuntungan lain yaitu dapat melayani kebutuhan siswa yang memiliki kemampuan di ata rata-rata. Artinya, siswa yang memiliki kemampuan belajar bagus tidak akan terhambat oleh siswa yang lemah dalam belajar.

Model pembelajaran inkuiri akan lebih efektif diterapkan apabila diperbantukan dengan lembar kerja siswa. Menurut Menurut Fathoni (2018) LKS merupakan bahan ajar yang dicetak dan berupa lembaran yang berisi materi, ringkasan, petunjuk, pelaksanaan tugas pembelajaran yang telah mengacu pada kompetensi dasar. Senada dengan pendapat Prastowo (dalam Wahidah, 2018) Lembar Kerja Siswa (LKS) adalah materi bahan ajar yang sudah dikemas sedemikian rupa, sehingga peserta didik dapat mempelajari materi ajar secara mandiri.

Sebanding dengan penelitian yang dilakukan Amalina (2018) yang berjudul pembelajaran guided inquiry erbantuan lembar kerja siswa untuk meningkatkan hasil belajar siswa. Hasil penelitiannya adalah pembelajaran dengan model guided inquiry dengan lembar kerja siswa dapat meningkatkan hasil belajar secara signifikan pada kelas eksperimen karena siswa kelas eksperimen lebih terbiasa membuktikan penyelesaian masalah yang disajikan oleh guru melalui demonstrasi atau percobaan sederhana.

Berdasarkan pemaparan di atas, terlihat pembelajaran inkuiri berbantuan LKS membuat siswa menjadi aktif, baik dengan sesama siswa maupun dengan guru. Hal ini membuat kemampuan kerjasama siswa menjadi meningkat. Apabila kemampuan kerjasama siswa sudah meningkat, tentunya akan membuat siswa lebih mudah memahami materi pembelajaran. Maka dari itu, dapat disimpulkan bahwa: secara bersamasama, terdapat pengaruh yang signifikan implementasi pembelajaran inkuiri berbantuan lembar kerja siswa dalam pembelajaran matematika terhadap kemampuan bekerjasama dan hasil belajar matematika siswa.

Temuan penelitian ini memiliki implikasi penelitian, sebagai berikut. (1) Penerapan pembelajaran inkuiri berbantuan lembar kerja siswa dapat memperbaiki proses pembelajaran. Guru dalam pembelajaran inkuiri berbantuan lembar kerja siswa adalah sebagai fasilitator yang mendorong siswa untuk belajar secara kritis, dalam aspek budaya dan kehidupan sosial siswa sehingga dapat meningkatkan kemampuan bekerjasama dan hasil belajar siswa. (2) Implementasi pembelajaran inkuiri berbantuan lembar kerja siswa dapat memberikan bantuan kepada siswa berupa petunjuk, dorongan, peringatan, menguraikan masalah-masalah kedalam langkah-langkah pemecahan, memberikan contoh, dan tindakan lain yang memungkinkan siswa itu belajar mandiri. Pemberian bantuan ini bertujuan agar siswa mampu menyelesaikan masalahmasalah yang diberikan secara mandiri.

\section{PENUTUP}

Berdasarkan hasil pengujian hipotesis dan pembahasan tersebut dapat disimpulkan, sebagai berikut. (1) Terdapat pengaruh yang signifikan implementasi pembelajaran inkuiri berbantuan lembar kerja siswa dalam pembelajaran matematika terhadap kemampuan bekerjasama siswa. (2) Terdapat pengaruh yang signifikan implementasi pembelajaran inkuiri berbantuan lembar kerja siswa dalam pembelajaran matematika terhadap hasil belajar matematika siswa. (3) Secara bersamasama, terdapat pengaruh yang signifikan implementasi pembelajaran inkuiri berbantuan lembar kerja siswa dalam pembelajaran matematika terhadap kemampuan bekerjasama dan hasil belajar matematika siswa

Adapun saran yang dapat diberikan berdasarkan penelitian yang telah 
dilakukan adalah guru hendaknya selalu berinovasi dan mengembangkan pembelajaran yang diterapkannya kepada siswa, sehingga pembelajaran menjadi bermakna dan menyenangkan bagi siswa.

\section{DAFTAR RUJUKAN}

Afriansyah, E.A. 2017. Desain Lintasan Pembelajaran Pecahan Melalui Pendekatan Realistic Mathematics Education. Jurnal Mosharafa, Volume 6, Nomor 3. 463-474.

Amalina, N.S., dkk. 2018. Pembelajaran Guided Inquiry Berbantuan Lembar Kerja Siswa Untuk Meningkatkan Hasil Belajar Siswa. Jurnal Tadris Kimiya Volume 3 No.1

Anggraini, B.N.W., dkk. 2020. Pengaruh Penerapan Model Pembelajaran Inkuiri Terhadap Hasil Belajar Tentang Sistem Gerak. Jurnal Pijar MIPA Volume 15 No.1

Ariyani, A.P.P., dkk. 2018. Pengaruh Model Pembelajaran Inkuiri Terbimbing Terhadap Kemampuan Mengenal Bentuk Geometri Kelompok B. e-Journal Pendidikan Anak Usia Dini Universitas Pendidikan Ganesha. 1-10.

Budiasih, Luh, dkk. 2017. Pengaruh Pendekatan Matematika Realistik Berbasis Pemecahan Masalah Terhadap Hasil Belajar Matematika Siswa Kelas V SD. e-Journal PGSD Universitas Pendidikan Ganesha Vol: 5 No: 2

Fathoni, I.M., dkk. 2018. Lembar Kerja Siswa (Lks) Fisika Berbasis Poe (Predict, Observe, Explain) pada Materi Medan Magnet SMAN Mumbul Sari. Seminar Nasional Pendidikan Fisika 2018, Jurnal Unej Vol.3 No 2

Kemendikbud. 2019. Laporan Hasil PISA 2018. (online) https://simpandata.kemdikbud.go.id/i ndex.php/s/tLBwAm6zAGGbofK\#pdf viewer

Khasanah, M.M. 2018. Profil Keterampilan Kerjasama Siswa Kelas VII Di Salah Satu SMP Swasta Di Magelang.
Jurnal Pendidikan Biologi Unimed Volume 7 Nomor 2 Halaman 132140

Laksana, D.,N.,L. 2017. The Effectivenessof Inquiry Based Learning For Natural Scineces Learning in Elementary School. Jurnal of Education Technology, 1(10), 1-5.

Nurmayani, Lia., dkk. 2018. Pengaruh Model Pembelajaran Inkuiri Terbimbing Terhadap Kemampuan Berpikir Kritis Peserta Didik. Jurnal Pendidikan Fisika dan Teknologi Volume 4 No.1. 98-104.

Ningrum, M.F.C.P. 2018. Upaya Meningkatkan Keterampilan Kerjasama Siswa Pada Bidang Studi IPA Melalui Penerapan Model Group Investigation Bagi Siswa Kelas 5 SDN Kumpulrejo 2. E-Jurnal Wahana Kreatifitas Pendidik Volume I Nomor 3

Nugroho, B.S. 2017. Pengaruh Penggunaan Media Roda Pengukuran Terhadap Hasil Belajar Siswa Kelas IV Materi Pengukuran Panjang Sdn Lidah Wetan II/462 Surabaya. JPGDS Volume 05 Nomor 03. 1531-1541

Pratiwi, I.A., dkk. 2018. Peningkatan Kemampuan Kerjasama Melalui Model Project Based Learning (Pjbl) Berbantuan Metode Edutainment Pada Mata Pelajaran IImu Pengetahuan Sosial. Jurnal Refleksi Edukatika Volume 8 Nomor 2.

Rawa, N.R., dkk. 2018. Pengembangan Bahan Ajar Matematika Model Inquiry Learning Berbantuan Perangkat Phet Simulation Untuk Meningkatkan Kemampuan Komunikasi Matematis Siswa Kelas VII SMP. Jurnal IImiah Pendidikan Citra Bakti Volume 5 Nomor 2

Rawa, N.R., dkk 2019. Pengaruh Model Inquiry Learning Terhadap Hasil Belajar Matematika Pada Siswa Kelas IV SD. Jurnal IImiah Pendidikan Citra Bakti Volume 6 No. 1 
Strike, B.L. 2018. Penggunaan Model Problem Solving Dalam Menyelesaikan Soal Cerita Matematika Di SD Al Hikmah Surabaya. JPGSD Volume 06 Nomor 03. 363-372.

Suciani, Luh, dkk. 2018.Pengaruh Metode Pembelajaran Make A Match Terhadap Kemampuan Bekerjasama Kelompok A Di Taman KanakKanak.e-Journal Pendidikan Anak Usia Dini Universitas Pendidikan Ganesha Volume 6 No. 2 Tahun halaman 199-206

Wahidah, N.,dkk. 2018. Pengembangan Lembar Kerja Siswa dengan Model Pembelajaran Koperatif Tipe KreatifProduktif untuk Memfasilitasi Kemampuan Pemahaman Konsep Matematis Siswa SMP Negeri 21 Pekanbaru. Juring (Journal for Research in Mathematics Learning) Vol. 1, No. 1

Widiani, A.A. O. V., Lasmawan, W., Suarni, K. 2020. Pengaruh Model Pembelajaran TGT Berbantuan Permainan Tradisional Terhadap Sikap Sosial dan Hasil Belajar PKn Siswa. Jurnal PENDASI: Jurnal Pendidikan Dasar Indonesia Volume 4 No. 1

Wiryawati, W., Dantes, N., Gunamantha, M. 2020. Pengaruh Pembelajaran Berpendekatan Saintifik Berorientasi Metakognitif Terhadap Hasil Belajar
Matematika Dengan Kovariabel Kemampuan Numerik. Jurnal PENDASI: Jurnal Pendidikan Dasar Indonesia Volume 4 No. 1 